\title{
DRØMMEN OM A BLI EN ANNEN.
}

(BY)VANDRINGENS BETYDNING I TOMAS ESPEDALS GA. ELLER KUNSTEN $\AA$ LEVE ET VILT OG POETISK LIV

\author{
KATARZYNA TUNKIEL
}

Adam Mickiewicz University in Poznań

\section{VERSITA}

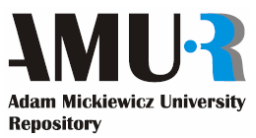

ABSTRACT. The paper gives an analysis of three functions of the

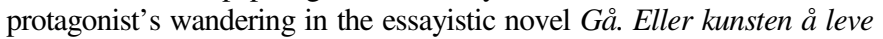
et vilt og poetisk liv (2006, Walk. Or the art of living a wild and poetic life) by the Norwegian author Tomas Espedal. The analysis is inspired by the interpretation of the novel by Finn Tveito (2010) and focuses primarily on wandering in urban space, in and around the cities of Bergen and Paris. The functions identified in the paper are: (city) wandering defined as a search of a metaphorical home, as acting realised on two different levels, and as a way to accept the protagonist's role as a writer. Apart from this, the paper is an attempt to portray the wanderer's identity as a postmodern man and an artist.

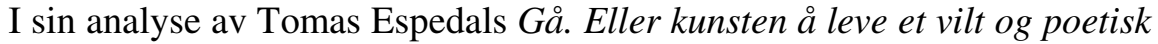
liv (2006) beskriver Finn Tveito i boka Det vandrande mennesket (2010:180196) flere av vandringens funksjoner i denne essayistiske romanen. Blant dem kan nevnes vandring oppfattet som et opprør mot det etablerte liv og moderne måter å reise på, begynnelse på en forvandling eller personlig utvikling, en fluktlinje i Gilles Deleuzes forstand, eller eksperimentering - for å "utvikla ein ny livsmodus der vandring står sentralt" og "gjera vandrerørsla til utgangspunkt for litterær skriving" (Tveito 2010:191). Tveito legger spesielt vekt på betydningen av vandring som en del av hovedpersonens/fortellerens større skriveprosjekt. Et av de viktigste poengene i Det vandrande mennesket er at det å gå og skrive er varianter av den samme, meningsskapende aktiviteten. Videre blir hovedpersonens vandreturer sett på som en forlengelse av den gamle europeiske vandretradisjonen, noe som tydeligst kan observeres når han går i fotspor til flere kjente kunstnere/vandrere.

Tveitos innsiktsfulle analyse gir et godt bilde av rollen som vandringsmotivet spiller i Espedals roman, men den er ikke uttømmende, 
særlig tatt $\mathrm{i}$ betraktning at det $\mathrm{i}$ en bok som handler om å gå finnes flere aspekter ved motivet som danner et svært rikt og komplekst betydningsunivers. Tveito unders $\emptyset$ ker hovedpersonens vandring slik som den forekommer i hele romanen: Selv om byvandring har en spesiell posisjon i interessekretsen hans ${ }^{1}$, skiller han ikke mellom turene som finner sted i naturen og de som foregår i byen. Tvert imot, han understreker naturens energigivende betydning under vandringen og ser nesten helt bort fra de scenene i Gå som utspiller seg i byrommet. Det er nettopp i disse passasjene det kan observeres noen andre funksjoner som vandringsmotivet har i romanen. Også hovedpersonens oppførsel og handlingsmåte i byene som han besøker ${ }^{2}$ forteller en del om hans identitet som vandrer, og bidrar dermed til å etablere et mer fullstendig bilde av både ham selv som en selvoppnevnt vagabond og vandringen hans forstått som et kall eller et helt unikt, alternativt yrke.

\section{BERGEN. MØRKET ER ET STED, LYSET ER EN VEI}

"Hvorfor ikke begynne med en gate" - slik lyder åpningssetningen i Gå. Den topografiske forankringen er veldig sterk helt fra begynnelsen: Den ovennevnte gata er Bjørnsonsgaten i Bergen. Også videre i romanen blir stedsangivelsene veldig nøyaktige, noe som blant annet gjør Espedals bok til en svært realistisk tekst. Hovedpersonen går inn mot sentrum, det er hans gamle adresse og "yndligsstrekning inn mot byen" (s. 11). Bevegelsesaksen hans har byen som et sentralt referansepunkt. Både Bergen $\mathrm{i}$ åpningsscenen og andre byer videre i romanen blir for ham steder som han orienterer seg etter romlig når han skal ut på en vandretur. Interessant nok oppfatter han retningen mot byen (eller bysentrum) som den rette, i hvert fall i begynnelsen. Når han skriver: "Jeg går i feil retning, ut av byen" (s. 22), blir det med et snev av overraskelse, da fortelleren/hovedpersonen ganske tydelig er et bymenneske som forlater det urbane rommet av bestemte grunner.

Begynnelsen på romanen er altså en skildring av byvandring som i tillegg forbindes med svært positive følelser: "[...] etter bakken mot Store Lungegårdsvann, på broen hvor fisken ligger og dør på asfalten, treffer sollyset et trafikkskilt og jeg blir truffet av en uventet lykkefølelse. Den sier ikke annet enn: du er lykkelig. Her og nå. Grunnløst. I dette øyeblikket er du lykkelig, uten grunn, som en gave" (s. 12). Denne beskrivelsen kontrasterer med en kort oppsummering av hovedpersonens nåværende situasjon: Han er "fyllesyk og

${ }^{1}$ Det lengste kapitlet i Det vandrande mennesket har byvandring som tema, mens boka mangler tilsvarende kapittel om vandring i naturomgivelser.

2 Det finnes tre lengre beskrivelser av byvandring i romanen: åpningsscenen i Bergen, oppholdet i Paris og besøket i Istanbul. Også andre byer, bl.a. Athen, nevnes kort i boka, men disse episodene er av langt mindre betydning med hensyn til byvandringsmotivet. Det er scenene som foregår i Bergen og Paris som blir mest relevante for denne analysen. 
nedtrykt etter å ha drukket sammenhengende i fire dager, bor alene i et skittent hus i en elendig gate, sover på en madrass, ingen møbler" (s. 12), han har nettopp blitt forlatt av sin kjæreste.

Allerede i denne korte passasjen kan man observere en klar motsetning mellom det å være ute og gå og det å være inne, hjemme. Det første kapitlet slutter med en erkjennelse: "Langsomt går det opp for meg, du er lykkelig fordi du går" (s. 12). Den positive innstillingen som hovedpersonen har til vandring blir videre kontrastert med en rekke mer negativt følelsesladede bilder av å være inne. Dette kan illustreres med en liste over utvalgte assosiasjoner med det å være inne, som knyttes til det å drikke, oppholde seg i et hus eller en bar, med elendighet, ødeleggelse og glemsel, mens det å være ute assosieres med å gå, befinne seg på en gate, og med følelser av lykke og håp. Slike polariserende begrepspar kan sammenfattes med Dylan Thomassitatet brukt av hovedpersonen når han forteller om drikkingen sin: "Mørket er et sted, lyset er en vei" (s. 17). Stillstanden blir da det negative elementet i dikotomien, og bevegelsen er noe nesten utelukkende positivt.

De ovennevnte motsetningene er likevel ikke helt entydige fordi det å drikke beskrives for eksempel som en av hovedpersonens gleder, en reise som en kan foreta "uten å bevege seg fra stolen" (s. 17), og baren han frekventerer sammenlignes med "et perverst hjem, en umulig stue" (s. 17). Det er kanskje ikke så overraskende at baren blir oppfattet av hovedpersonen som et slags hjem, tatt $\mathrm{i}$ betraktning at både $\mathrm{i}$ baren og hjemme $\mathrm{i}$ huset sitt føler han seg på den ene side forholdsvis trygg, men på den annen side har begge stedene en slags $\varnothing$ deleggende kraft i seg.

\section{BERGEN OG OMEGN. VANDRINGEN ER EN ØNSKET ELLER UØNSKET HJEMLØSHET}

Fortelleren bekjenner at han ikke kan bo i et hus, at han foretrekker små leiligheter. Det å bo "i det morderiske huset" (s. 25), som han kaller det, hindrer ham fra å reflektere og skrive ("I mitt tilfelle fører store hus til små tanker", s. 25), og vekker en trang til å gå bort derifra og starte på en vandring. Han mener: "Det å gå er, i en viss forstand, det motsatte av å bo i hus. Det gjelder $\mathrm{i}$ alle fall vandringen, som en forlenget, frivillig eller ufrivillig gåerfaring, vandringen er en ønsket eller uønsket hjemløshet.” (s. 25) Denne metafysiske hjemløsheten sammenstiller Finn Tveito med det å være hjemmefra i en konkret forstand, etter å ha lagt bak seg "det trygge livet som blir levd når ein bur i eit hus, har ein jobb, osb." (Tveito 2010:191). Men Espedals hovedperson er i en situasjon som er lang fra det en kan kalle for et trygt og etablert liv. Han er blitt alene og har ikke noen fast jobb, det eneste han liker er å skrive, tenke og gå. Derfor velger han å forene alle disse aktivitetene $\mathrm{i}$ én og bli en slags profesjonell vandringsmann. Det å være 
hjemmefra gir ham frihet (etter hvert en "frihetsrus", som Tveito påpeker), men denne friheten virker heller som en redning, og ikke som en frigjøring fra den monotone hverdagen.

Hjemløshet kan også innebære at man forventer eller håper på å finne et hjem, som i dette tilfellet ikke nødvendigvis befinner seg der hvor man bor. Nina Witoszek (1998) har på bakgrunn av sin analyse av Munch og Ibsens verk formulert en påstand om at det er ute i naturen hvor hjemmet egentlig er for nordmenn (original kursivering): "Det viser seg som oftest at det er ute som er hjemme, at det er der man kommer med kontakt med sitt egentlige jeg, mens det faktiske hjemmet er et klaustrofobisk, fremmedfølelsens sted" (Witoszek 1998:103). Her må det bemerkes at hun ikke definerer hjemmet som et konkret sted, men heller som et begrep tilhørende "en arketypisk, figurlig virkelighet" (Witoszek 1998:97). Det er en slik forståelse av hjemmet som også blir aktuell for denne analysen, i tillegg til det konkrete hjemmet, dvs. det fysiske stedet hvor man bor eller i alle fall oppholder seg i lengre perioder.

Påstanden til Witoszek kan være ganske riktig også for Espedals hovedperson, da det er ute han føler seg fri og selvoppfylt, der oppnår han selvinnsikt og får inspirasjon til å skrive, mens det å være inne trenger han bare for å kunne utføre selve skriveprosessen. Etter Gaston Bachelard (1994) kan en si at alt som er ute - det være seg naturen eller byen - er hovedpersonens lykkelige rom (l'espace heureux), noe som kan virke i strid med den franske filosofens typiske forestillinger om topofili, eller bevisstheten om det elskede, lykkelige rom. For ham er hus tett knyttet til lykken, det er huset som beskytter dagdrømming og lar en tenke og drømme i fred (Bachelard 1994:6). For Espedals hovedperson er husets betydning litt annerledes: Han tenker best når han går, men etter den hvileløse vandringa har han også sterk behov for denne beskyttelsen - freden og roen som et hus gir for dermed å kunne arbeide.

Forholdet mellom det å gå, være inne og det å skrive, danner en svært vesentlig trekant i $G a ̊$. Vandring er nødvendig for å skrive, men det å være inne - som ikke er det samme som hjemme - behøves for at hovedpersonens ideer skal få en skriftlig form ("et tomt hus, en tom stue, et tomt rom, det får meg til å skrive", s. 49; "[J]eg kan skrive hvor som helst, alt jeg trenger er et bord og en stol. Alt jeg trenger er å være inne”, s. 63). På den annen side kan fortellerens opphold innendørs utløse i ham trangen til å gå ut. Samtidig påvirker vandringen hans måten han oppfatter det å være inne på: Det er godt å komme i hus etter å ha gått lenge, og omvendt - det er godt å gå ut når man vet at det finnes et sted å komme tilbake til ("Gleden ved huset er gleden ved å være inne. Gleden ved å være ute skyldes at man har funnet et hus, det behøver ikke være ditt eget", s. 62-63). 
Det som er viktigst når det gjelder disse relasjonene er at alle elementene $\mathrm{i}$ trekanten er uunnværlige og påvirker hverandre. Her kommer vi også tilbake til spørsmålet om hva som er hjemmet for hovedpersonen. En kan ha lett for å legge merke til at det er viktig for ham å ha et sted hvor han kan arbeide, men som han selv innrømmer, han kan ikke bo:

Jeg har ofte villet bo, men har aldri klart det. De gangene jeg ville bli boende, skjedde det alltid et eller annet som gjorde det nødvendig å flytte. Som Klaus Høeck drømmer jeg om å skrive en bok om alle adressene jeg har hatt; gatene, leilighetene, byene, rommene, husene, alle disse umulige stedene vi kaller hjem. (s. 64)

Rastløsheten til Espedals hovedperson fører til at han velger å gå for dermed å oppleve en eksistensiell ro. Det er derfor mulig å tolke vandringene hans som et fors $\varnothing \mathrm{k}$ på å finne et ikke-konkret hjem, som en konstant leting etter noe å holde fast til, noe stabilt, uforanderlig og sikkert i livet.

\section{PARIS. FORKLEDD I EN FREMMED BY}

Når fortelleren i $G a ̊$ nevner for første gang Charles Baudelaire, "alle flanørers far" (s. 33), merker han at for den franske dikteren var gatene et hjem, mens leiligheten hans ble omgjort til en gate. Denne forvirringen i inne/ute-forholdet virker sann også for Espedals hovedperson, i hvert fall når det gjelder forestillingen om det urbane rommet som et hjem. Denne engasjerte vandreren med forkjærlighet for storbyer blir i romanens andre del til en flanørlignende figur, men for at dette skal bli mulig, må han først oppfylle forutsetningen om en viss anonymitet som er et av flanørens mest typiske trekk. Dette oppnår han med hjelp av en forkledning.

Når han ankommer Paris, etter en spontan kjøretur fra Bergen gjennom halve Europa, får oppholdet hans helt fra begynnelsen et tydelig preg av en storbyopplevelse:

Jeg gikk inn i byen ved Porte de Clignancourt, kolliderte med gatene og menneskemylderet; en plutselig vegg av by og støy. Jeg gikk gjennom bydøren og ble blendet av lyset, bylyset; et virvar av ansikter og hender, øyne og hus, vinduer og gater, av dører og muligheter; hvor skulle jeg gå? (s. 117f.)

Den første forfjamselsen blir fort erstattet med en innsikt at han har klart å oppfylle det store ønsket sitt om en forvandling, "drømmen om å bli en annen" (s. 18), "om å våkne opp til et nytt liv", som han kaller det (s. 20). Han ser seg

${ }^{3}$ Ved siden av bl.a. motivet om å skrive og være forfatter er hus-/hjemmotivet en av gjengangere i Tomas Espedals forfatterskap. Det er sentralt f.eks. i hans neste bok, Imot kunsten (notatb $\phi k e n e)(2009)$. 
i speilet og oppdager at han etter den lange vandreturen gjennom Frankrike ligner en uteligger, en boms. "Sånn hadde jeg alltid lyst til å se ut" - tilstår han. $-[\ldots]$ Endelig var jeg i godt humør, endelig var jeg fremme: jeg var blitt en annen." (s. 118)

Den fysiske forvandlingen blir for ham starten på noe som en kan kalle for en fortidsorientert byvandring eller en dialog med 1800-tallets byvandringstradisjon. Det nye utseendet, den nye forkledningen gir hovedpersonen den nødvendige anonymiteten som lar ham vandre uten mål og mening rundt den franske hovedstadens gater og gjør ham dermed til en etterfølger av både flanøren, den moderne maleren slik han blir beskrevet av Charles Baudelaire i Kunsten og det moderne liv (2000), og mannen i mengden fra Edgar Allan Poes berømte novelle med samme tittel. Byvandreren i Espedals roman sitter på kafeer, observerer folk, suger inn inntrykk, gjør notater til boka si, og ikke minst driver dank - han gjør altså alt det som var flanørens typiske beskjeftigelser.

Det kan se ut som om Paris selv krevde at han skulle spille rollen som en nonchalant omstreifer. Men denne byen, til tross for sin lange tradisjon for å flanere, er ikke lenger den Hausmanns Paris som inspirerte utallige kunstnere og vagabonder. Den er blitt til en postmoderne, flerkulturell metropol, noe som hovedpersonen først legger merke til når han besøker en av de "afrikanske" forstedene til Paris. Der innser han at han hittil har gått "i en fortidsforestilling, i en by som ikke fantes" (s. 122), en by til den franske avantgardekomponisten Erik Satie som han går i fotspor til. Med andre ord vil han høre til et av de nedre lagene i byens palimpsest, men han begrenses av nåtidens Paris.

Dissonansen mellom forestillingene hans og virkeligheten understrekes i tillegg av utseendet som beskrives slik: "Jeg var en latterlig figur. Kledd i dress og hvit skjorte med blod på snippen og skjortebrystet. Jeg blødde neseblod. Det var på grunn av all eksosen. Jeg gikk i utslitte sko og skitne bukser, en lærveske over skulderen. I vesken: en penn og notatbøkene" (s. 122). Dette bildet viser nøyaktig hvem han er: en mistilpasset dagdrømmer, en romantiker som plutselig finner seg selv i det 21. århundret. Likevel er denne nesten groteske eller camp-aktige fortidsfiguren klar over at Parisvandringen hans bare er et spill, noe kunstig og tilgjort som han samtidig ikke kan motstå: "Niogtredve år gammel burde jeg visst bedre, men likevel gikk jeg ned gaten Leclercq og ville tilbake i tid: jeg ville gjøre noe som ikke lenger var meg" (s. 123).

Hovedpersonens oppførsel i den franske hovedstaden virker enda mer som en positur når den sammenstilles med det senere besøket hans i Istanbul. I Paris, akkurat som under fjellturene sine i Sunnhordaland, går han med dress og hvit skjorte nettopp for å understreke at han ikke er som de andre vandrerne eller turistene, at han skal være den stolte videreføreren av det gamle vandreryrket og den som samtidig vil beære sine forgjengere. Han er en annen, 
også i hverdagslig forståelse av ordet, derfor vil han skille seg ut. I Tyrkia derimot, hvor han ikke går $\mathrm{i}$ fotspor til noen kjente kunstnere, blir både forkledningen hans og rollen den spiller helt annerledes. Der fors $\varnothing$ ker han å se ut akkurat som den lokale befolkningen for å "gli ubemerket inn i byens mylder" (s. 183). Han behøver altså en annen type anonymitet - ikke for å påta seg en ny, alternativ identitet, men tvert imot, for å skjule sitt ekte jeg.

Men i Frankrike er Espedals hovedperson som en skuespiller i et teater av bygater, han bærer en maske som gjør ham til en som, for å bruke Baudelaires formulering, "overalt nyter sin inkognito" (Baudelaire 2000:111). Likevel er det ved to anledninger når masken hans faller, hans andre jeg fortrenges og han blir igjen til én person. Første gang skjer det når en kulturjournalist $\mathrm{i}$ Bergens Tidende kjenner ham igjen på gata. Vandreren reagerer sterkt på dette plutselige møtet:

Jeg stanset, det var ubehagelig, som å bli arrestert, like før man er i ferd med å begå en forbrytelse. [...] Var jeg ikke forkledd i en fremmed by, ukjent for alle? Hadde jeg ikke skjulte hensikter, hemmelige planer, planer som tilhørte en annen: han som gikk ukjent og fri langs gatene i Paris? [...] Men noe var forandret. Noe var ødelagt, jeg var ikke lenger en fremmed. Jeg var ikke lenger en annen, jeg var blitt innhentet, i løpet av noen minutter var jeg blitt meg selv. (s. 123-124)

Den andre anledningen er et annet møte, denne gangen med en tigger som er hovedpersonens dobbeltgjenger. Igjen er reaksjonen sterk, nesten panisk: "Jeg fikk nærmest sjokk og måtte stanse, han hadde mitt ansikt. [...] Jeg skalv av opphisselse. [...] Jeg ble stående fast. En sigarett. Ett skritt frem, ett tilbake; jeg ville ikke vite noe om denne mannen, rev meg løs og hengte meg fast i en forbipasserende [...]" (s. 132). I denne projiserte karakteren avspeiles fortellerens frykt for en fast forvandling, for at den andre i ham selv skal overta og forandre ham til en av byens ekte uteliggere. Eller med andre ord: Frykten for at spillet hans kan bli til virkelighet. Derfor flykter han fra møtestedet. Etter å ha blitt konfrontert med sitt andre jeg slutter Espedals hovedperson å late som om han var en han ikke er, han blir bare seg selv igjen. Slik avsluttes hans eksplisitte spill i metropolens gater, men spillmotivet videreføres på et annet plan, i sammenheng av en større, metaforisk forestilling.

\section{PARIS. SOM FIGURENE I ET SKYGGESPILL, ET MARIONETTETEATER}

Midt i en lengre passasje skrevet med bruk av en stream of consciousnesslignende teknikk, snart etter møtet med tiggeren, stilles hovedpersonen i en ny posisjon av en tilskuer. Akkurat som da han var barn og så fra stuevinduet på et gjestehus i Bergen, får han fra sitt hotellværelse innblikk i det som foregår i en bar overfor. Baren beskrives ved hjelp av en sammensatt teatermetafor som 
hentyder både til de platonske og shakespearske motivene, der gjenstander og mennesker er "som figurene i et skyggespill, et marionetteteater" eller en dukkeforestilling "basert på Hoffmanns Eventyr med musikk av Offenbach" (s. 133). Han som for ikke så lenge siden selv spilte en forvrengt flanør i Paris' gater blir til en observatør av virkeligheten framstilt som et skuespill. Dermed realiserer Espedal teatrum mundi-toposen på minst to ulike nivåer ${ }^{4}$.

Tilskuerrollen er nødvendig for at hovedpersonen skal "opprettholde en avstand" (s. 134) eller rense sinnet for å kunne skrive. Men de frigjorte tankene begynner raskt å ta form av en slags avspaltet karakter, eller fortellerens nye, alternative jeg, som i likhet med tittelpersonen i H.C. Andersens kjente fortelling, kalles for skyggen. Mest påfallende ved denne figuren er at den etterligner hovedpersonens utseende og vaner, særlig de som er knyttet til byvandring. Som det ofte skjer med slike projiseringer, avspeiler den avspaltede karakteren fortellerens ubevisste drømmer og ønsker; han blir altså til en svært nysgjerrig og dristig vandrer:

Du sitter i vinduet på hotellrommet og røyker en sigarett, han går gjennom byen og leter etter noe du ikke vil vedkjenne deg, som om han har overtatt dine hemmeligheter, dine innerste impulser og mørkeste ønsker, som om han har gjort dem om til en slags motor, en mekanikk, en drivkraft, en indre fjær som trekker ham opp og skyver ned den gaten du ikke burde gå. (s. 134-135)

I en senere scene som på en og samme tid skildres som en voyeuristisk fantasi og en drømmeaktig teateroppstilling, oppsøker skyggen en kvinne framstilt som "en dukke av tøy" (s. 135). Den mannlige figuren engasjerer seg da i et spill der både han og kvinna fremfører sine roller, men uten noen særlig innlevelse - spillet deres blir bare en rent mekanisk gjentakelse av bevegelser og replikker, noe som forsterker inntrykket av denne scenens kunstighet og uvirkelighet. På grunn av sin indre splittelse kan Espedals hovedperson fungere både som tilskuer og skuespiller, selv om det er den første av aktivitetene som faktisk finner sted, mens den andre bare er forestilt.

Med den gjennomgående anvendelsen av både dobbeltgjenger-motivet og teatrum mundi-toposen oppnår Espedal et bilde av en uvirkeliggjort verden hvor hovedpersonen framstilles som en outsider som tydelig vil ta avstand fra det etablerte liv (i Tveitos forstand) for dermed å kunne lete etter et hjem og/eller søke selvoppfyllelse som forfatter. I storbyen bærer hovedpersonens oppførsel ikke så mye preg av et opprør eller en flukt fra det moderne samfunn, men snarere av en markering av egen annerledeshet og manglende tilpasning til de eksisterende normer.

${ }^{4}$ Bortsett fra de analyserte passasjene, forekommer toposen også andre steder i $G a ̊$, f. eks. i beskrivelsen av en drøm der fortelleren blir både tilskuer og deltaker i en teateroppsetning av Shakespeares En midtsommernattsdrøm. 
Alt det kunstige og overdrevne som kjennetegner beskrivelser av byen og byvandring i $G a ̊ a j ø r$ at verden som Espedals hovedperson befinner seg, og ikke minst beveger seg i, kan oppfattes som en slags kulisse: en midlertidig og unaturlig setting, underlagt noen regelmessige endringer. Denne forestillingen er kanskje mest gjeldende for hotellværelser hvor han, på ulike tidspunkter i sitt liv, tilbringer store deler av tiden i Paris. De virker som teaterdekorasjoner som får ham og andre personer til å gå inn i bestemte roller, slik det skjer med fortelleren som 16-åring og hans kjæreste, som begge blir inspirert av en spesiell innredning i hotellrommet de får, og helt uventet starter en litt ubehagelig, erotisk lek (se s. 136-141). Falskheten ved slike steder kan også styrke hovedpersonens trang til å forlate dem for å søke et ekte hjem, ikke bare et metaforisk hjem for seg selv, men også noen helt konkrete hjem eller hus til fortidens kunstnere og vandrere som han er så opptatt av.

I Espedals Paris er hovedpersonen ikke den eneste som blir nødt til å spille en annen. Den franske hovedstaden blir nemlig skildret i romanen som et sted hvor spill, teater og erotikk glir inn i hverandre i en framstilling tenkt som en lek med stereotypiene om Paris som kjærlighetens og kunstens by. Bortsett fra hovedpersonens kjæreste fra ungdommen finnes det i $G a ̊$ en rekke personer som spiller bestemte roller, påtar seg andre identiteter eller i alle fall skjuler hvem de egentlig er: den ukrainske prostituerte Vivianne som fortelleren treffer, de mannlige elskerne fra naborommet hans, og ikke minst skulptøren Alberto Giacometti som han vier en lengre passasje til, og som aldri skiftet klær, fordi det for ham ikke fantes noe "skille mellom liv og arbeid, mellom hverdag og arbeid, kunst og arbeid, alt var arbeid, også besøkene på bordellet" (s. 127).

\section{PARIS OG OMEGN. MEN HVOR ER HJEM...?}

Giacomettis prinsipp synes å være aktuelt også for Espedals hovedperson. Under byturene sine iakttar han omgivelsene for deretter å skrive ned sine observasjoner. Han går for å skrive, og begge aktivitetene kan regnes som to sider ved samme arbeidsprosess. Slik etablerer han sitt selvbilde som en håpefull kunstner og vagabond, men likevel er det noe som tyder på at han behøver å få godkjent identitetskonstruksjonen sin. Det faktum at han følger i fotspor til ulike tidligere vandrere/kunstnere kan leses som et tegn på hans forholdsvis lave selvsikkerhet i forfatterrollen. Ved å videreføre det gamle "vandreryrket" forsøker han samtidig å bekrefte sin egen verdi som dikter og menneske, bevise at veien han har gått for å gjøre det han gjør i livet er veldig lik den veien som andre, berømte kunstnere gikk før ham.

Ikke minst er det påfallende at hovedpersonen besøker husene til sine vandrende forgjengere. Dette har tydelig en symbolsk dimensjon som kan knyttes til Bachelards allegoriske forestilling om huset som både et intimt 
tilfluktssted - et konkret hjem - og en vugge: stedet hvor alt har sitt opphav. Etter å ha funnet huset hvor Arthur Rimbaud hadde vokst opp og skrevet En årstid $i$ helvete, innser fortelleren:

[...] det slo meg først da jeg sto foran huset, at jeg hadde funnet stedet som var utgangspunktet for min egen skriving: huset hvor den unge gutten bodde sammen med sin mor. Den unge gutten som ville gjøre opprør, som ville reise bort, gå ut, som ville leve den frie friheten. Den unge gutten som ville skrive. Som ville leve et vilt og poetisk liv. Som ville se, som ville gå. Strekningen Rimbaud. (s. 144-145)

Hvis vi kommer tilbake til trekanten: gå, være inne og skrive, vil vi observere at det ikke bare er bevegelsen som hovedpersonen trenger for å kunne arbeide som forfatter. Det viser seg nemlig at kategorien som her bare kalles for "det å være inne" ikke må reduseres til en enkel oppfyllelse av fortellerens behov for et arbeidssted. "Inne" er begynnelsen, utgangspunktet, både for livet, vandringene og forfatteryrket. "(J)eg sto her foran huset i Roche og kunne kalle meg forfatter" (s. 145) - sier fortelleren og får dermed bekreftet selvbildet sitt. Her slutter også vandringa hans forstått som en vei mot bedre selvaksept og selvfølelse knyttet til forfatterrollen.

Og det er nettopp lengselen etter å skrive, å utføre forfatterarbeidet, som får fortelleren til å vende hjemover: "Mannen med fiskestangen hadde minnet meg på arbeidet mitt. Gleden ved å sitte ved skrivebordet. Blyantene, pennene, skrivemaskinen. En termokanne med kaffe, nistepakke, sigaretter. Jeg ville hjem" (s. 149). Men hvor er dette hjemmet? I hovedpersonens verden blir det enten ethvert sted hvor han kan skrive, dvs. hver bopel og hvert midlertidig husly, eller det metaforiske hjemmet, fortellerens lykkelige sted, som kan ta form av alle områder hvor han både føler seg fri og rolig, og har muligheten til å søke tilflukt (dvs. finne husly). Den åpne slutten på sistnevnte scene tyder på en tolkning som går i retning mot det andre alternativet. Vandreren går forbi en hage hvor han treffer en kvinne som spør ham hvor han skal. Da svarer han: "Jeg er på vei hjem, sa jeg. Men hvor er hjem, du er ikke herfra, sa moren. Jeg er fra Norge, sa jeg. Skal du gå helt til Norge? spurte hun som må ha vært moren, men jeg svarte ikke, jeg hadde allerede gått forbi" (s. 150). Kanskje vandringen er en hjemløshet, men selve veien kan også være et hjem.

Zygmunt Bauman (1996) skiller mellom fire ulike postmoderne livsstrategier: den spaserende (the stroller), vagabonden, turisten og spilleren (the player). Ifølge denne typologien blir Espedals hovedperson et godt eksempel på samtidens vagabond med noen felles trekk med turisten (selv om det må huskes at han stiller seg svært kritisk overfor turismen som en form for dagens byvandring). I tillegg spiller han (men i en annen forstand enn Baumans) den tidlig moderne spaserende, flanøren, dog selv er han fjern fra å 
realisere flanørrollen i dens postmoderne utgave. Som vagabonden uten noen fast reiseplan er han den fremmede som aldri får bosette seg noensteds, han er hjemløs, stadig på leting etter både det ikke-konkrete hjemmet og nye steder hvor han kan finne husly.

Men, paradoksalt nok, som turisten frykter han det å være knyttet til et sted, han rammes av det som Bauman kaller for "the fear of homeboundedness, of being tied to a place and barred from exit." Videre skriver han: "Home' lingers at the horizon of the tourist life as an uncanny mix of shelter and prison. The tourist's favourite slogan is 'I need more space'. And the space is the last thing one would find at home" (Bauman 1996:31). Forholdet som hovedpersonen i $G a$ har til det å bo/oppholde seg i et hus er preget av lignende ambivalens. Hans indre $\emptyset$ nske til å gå ut skyldes kanskje også det han aller mest drømmer om - drømmen om å bli en annen. Den postmoderne identiteten til Espedals vandrer kjennetegnes av en eksistensiell uro og et konstant behov for endringer i livet, av en opprørsk holdning "against 'strings attached' and long-lasting consequences" (Bauman 1996:33). Alt dette fører til at han blir vandringsmann, for bare det å gå avspeiler hans flytende, kunstneriske personlighet. Og det er i den postmoderne byen, med dens skiftende rytme og impulser, dens flytende menneskemasser, hvor denne siden ved personligheten hans hører hjemme. Der blir vagabonden skuespiller, tilskuer, forfatter.

\title{
LITTERATUR
}

Andersen, Hans Christian. 1977. Skyggen. Samlede Eventyr og Historier. Bind I. København: Gyldendal, s. 379-390.

Bachelard, Gaston. 1994. The Poetics of Space. Oversatt av Maria Jolas. Boston: Beacon Press. Baudelaire, Charles. 2000. Kunsten og det moderne liv. Oversatt av Arne Kjell Haugen. Oslo: Solum.

Bauman, Zygmunt. 1996. From Pilgrim to Tourist - or a Short History of Identity. I: Hall, Stuart \& Paul du Gay (red.) Questions of Cultural Identity. London: Sage Publications, s. 18-36.

Espedal, Tomas. 2006. Gå. Eller kunsten å leve et vilt og poetisk liv. Oslo: Gyldendal.

- 2009. Imot kunsten (notatbøkene). Oslo: Gyldendal.

Poe, Edgar Allan. 2008. The Man of the Crowd. Selected Tales. Oxford: Oxford University Press, s. 84-91.

Tveito, Finn. 2010. Det vandrande mennesket. Oslo: Novus.

Witoszek, Nina. 1998. Norske naturmytologier. Fra Edda til фkofilosofi. Oversatt av Toril Hanssen. Oslo: Pax.

\author{
Katarzyna Tunkiel \\ Uniwersytet im. Adama Mickiewicza w Poznaniu \\ Katedra Skandynawistyki \\ Collegium Novum \\ al. Niepodległości 4 \\ 61-874 Poznań \\ Poland \\ katszu@amu.edu.pl
}

